\title{
An Analysis of the Lagging Behaviors of Disciplinary Services in University Libraries
}

\author{
Yang Xing \\ Jilin Agricultural University, Changchun 130118, China \\ 37566208@qq.com
}

Keywords: university library; discipline service construction; book quality; control system.

\begin{abstract}
Library construction is a key problem in the construction of colleges and universities, and the construction of the library is better. Students can obtain the desired knowledge as part of the supplementary learning. At present, the construction of university libraries in China is still far from the gap between foreign universities. There are many reasons for this phenomenon, mainly because of the lack of emphasis on the leadership of colleges and universities, the lack of library construction and the low quality of library management, The quality of library books is not high, the lack of effective publicity, regulatory system defects and so on. This paper analyzes the causes of the lagging of university library construction and puts forward the corresponding measures.
\end{abstract}

\section{Introduction}

Disciplinary service is an important function of the library. The fundamental purpose of carrying out the discipline service is to make the resources in the library provide some help for the construction of the university discipline. Subject services are carried out by the subject librarians, subject librarians according to their professional needs, make full use of the resources in the library to help readers to assist the subject of knowledge learning. Disciplinary service is characterized by the library through the platform to provide readers with personalized reading services, so that each reader can get their own knowledge needs. The birth of the discipline service is the result of the development of the times. At present, the students' requirements for the library have been greatly improved compared with the previous ones. The demand of the students has not only been able to read the books from the library, Personalized service.

\section{Foreign University Library Discipline Service and Domestic University Library Discipline Service Comparison}

The academic service representative of foreign university library is the United States, this article focuses on the analysis of American subject service. The development of American subject service has been a long time, the theoretical system is perfect. The results of theoretical research in the United States show that the discipline service is the development trend of the university library, is the trend. Researchers in the United States believe that the era of traditional information-oriented has passed, knowledge-oriented era is coming In this era, people have no interest in the acquisition of information, because the development of today's Internet information technology, broaden the way people access to information, shorten the time for people to obtain information, in the past, people get information may Bashan wading to find newspapers or books, and now use the mobile side and the Internet, people can quickly and easily access information. In the present, people's demand for knowledge is greater than before, and knowledge and information are different, want to acquire knowledge or have some difficulties. In this era of great times, disciplinary services have emerged. The Internet makes a variety of information together, the sharing of resources more quickly, which also to promote the discipline to provide a lot of convenience. However, the discipline service will make the library more professional characteristics, which also the library manager's personal qualities put forward higher requirements. 
Professional library staff to do the basic needs is to have the relevant professional knowledge, to provide readers with some professional knowledge of the class services. American university library discipline construction time is very long. The earliest discipline service was at the University of California Library in 1950. Since the beginning of the new century, the construction of library services in American colleges and universities has been more rapid. The results of the 2010 survey show that more than $90 \%$ of university libraries in the United States have carried out discipline service construction, and the management system is very perfect, and the discipline service can play its own function well. In addition, the scope of coverage is quite extensive. Most of the academic services of American university libraries are carried out for two disciplines, covering almost all disciplines. Library subject librarians set is also very reasonable, according to statistics, the vast majority of prestigious universities in the United States the number of subject librarians are more than the total number of college disciplines. Subject librarians training work is quite perfect, each subject librarian has a very strong professional ability, in addition to training work, the assessment system, reward and punishment system, recruitment system is very perfect, subject librarians know that they can What to do, what should I do. Service and service concept is also very advanced. In addition to the work of the library in the foreign university library, most of the subject librarians have their own research work, which makes each of them have very high professionalism, which may also be domestic The gap between subject librarians and foreign subject librarians.

In contrast, China, the current construction of academic services is worrying. Compared with the characteristics of the early and late development of university libraries in China, the discipline service in China was relatively late. In 1993, Li Xi was published in the "Journal of the Chinese Library" in the "university library professional integration Service model "for the first time put forward the concept of subject service. China's scholars generally regarded this article as the originator of our subject service. After a certain theoretical basis, in 1998, Tsinghua University Library officially began to create a disciplinary services, set up a subject librarian, is the first university in China's subject library services. With many years of development, many of our university libraries have carried out the construction of discipline services. In the course of the development of subject service, our country's subject service embodies different development process from foreign universities. And the status of the development of subject services in each region of the country is very different from that of other regions. Key universities and subordinate colleges and universities on the degree of emphasis on disciplinary services is generally large, the development of disciplinary services is very rapid, and in some colleges and universities and local colleges and universities, discipline services are often not taken seriously, development is also severely blocked. On the whole, the construction of subject service of university library in our country is very different from that of foreign countries.

\section{The Reasons for the Backwardness of the Discipline Service of Chinese University Libraries}

\subsection{School Leadership Awareness Is Not Enough.}

University library is an important place for teachers and students to acquire knowledge, to the teachers and students of the study and research work to provide a literature support for the development of colleges and universities also have very important significance. However, the current level of leadership of our university has not paid enough attention to the discipline service, ignoring the significance of the discipline service in the construction of colleges and universities. The development of the library requires a lot of financial support and human support, and because the leadership of the library discipline service construction does not attach importance to the library can not get strong financial support and human support, resulting in the library when the purchase of books can not choose those Quality, and teachers and students of the study and research really meaningful books. Collection as the core content of the library, if the collection quality is not high, then the library services will be out of the question.

\subsection{Lack of Library Construction Talent.}

Colleges and universities in the construction of the library, the excessive emphasis on collection quality and library size, ignoring the importance of talent. China's many colleges and universities now 
in the library construction, blindly expand the size of the library and the number of collections, while ignoring the needs of teachers and students, making the development of university libraries from the right direction farther and farther. In addition, many of our colleges and universities will be the library as a college staff "shelter", which led to the staff of the library is basically no ability to work, the overall staff of the library is low, more unable to do a good job The work of the library.

\subsection{Library Construction in the Wrong Direction}

construction concept behind. Libraries exist in colleges and universities as a part of secondary school teaching. Students in the classroom can not learn or do not learn the knowledge, you can through the library platform for auxiliary learning. China is currently a lot of school administrators generally believe that discipline construction is the college and the teacher thing, dilute the library in the discipline construction role. This makes the library in the discipline construction role is getting smaller and smaller, to a certain extent hindered the speed of discipline construction, but also restricts the development of university library discipline services.

\subsection{Propaganda Is Not Enough}

The essential reason for the lack of propaganda is that the leadership of the school does not have a right person and a lack of attention to the situation of the library. Disciplinary services in China's development time is still relatively short, many people on the degree of awareness of academic services is not enough, the library on the discipline services publicity is relatively small, resulting in many students do not know the library to carry out the discipline services. Students do not pay attention to also reduce the subject librarians of the enthusiasm of the discipline services, leading to the quality of disciplinary services has repeatedly declined.

\subsection{Discipline Librarian's Own Quality Is Low}

the system is flawed. The individual qualities of subject librarians directly determine the quality of subject service. Many colleges and universities in our country when the construction of disciplinary services too hurry, the subject librarian carried out some simple training so that they rush posts. Which led to the quality of these subject librarians lower, can not meet the needs of academic service construction, can not be very good to complete their work. In addition, the existence of management system defects is also an important reason for the development of subject service in China. As China's discipline service construction started late, a variety of systems are also very imperfect, which led to a lot of subject librarians work enthusiasm is not high, which also seriously affected the development of academic services.

\subsection{Regional Imbalances Are Also an Important Factor}

Metropolitan colleges and subordinate colleges and universities due to the advantages of policy and geographical conditions, in the development of the time is easy access to the outside world of advanced technology and advanced concepts. And the remote location of some colleges and universities due to traffic inconvenience and lack of information exchange reasons, can not quickly get fresh knowledge, understanding of the discipline services is also relatively backward, which resulted in the development of different regional disciplines of the phenomenon of imbalance. Reducing the overall level of our subject services.

\section{The Improvement Measures}

The development of disciplinary services is a long-term process that requires long-term efforts from all sides. First of all, the school leaders to have enough attention to the library, the only way to get the development of the necessary human resources and material resources. Second, the library in the recruitment of subject librarians, we should pay attention to the selection of talent, a lot of selection of some of the higher quality of personnel, so that they can effectively for the construction of disciplinary services offer advice and suggestions. Then, the library to establish a scientific and sound management system, so that discipline services in the system under the management of healthy development. Finally, we should increase the publicity of library discipline services. When we carry out the construction of library subject service, we can not uphold the idea that "wine is not afraid of alley deep". We should increase the propaganda so that students can There is a clear understanding of the status of subject services. 


\section{References}

[1]. Journal of Library and Information Sciences in Agriculture]. Journal of Library and Information Sciences in Agriculture]. Journal of Library and Information Sciences in Agriculture]. Journal of Library and Information Sciences in Agriculture]. Journal of Library and Information Sciences in Agriculture]. Journal of Library and Information Sciences in Agriculture].

[2]. Zhu Hengxian. University library subject knowledge service real situation and realization of the way [J]. Cultural and educational materials, 2016 (33): 81-82.

[3]. Wang Xuefang. University library discipline service system system research [J]. Library and Information Work, 2013, 57 (9): 23-26.

[4]. Huang Haobo. Internet + environment Guangxi university library discipline service research [D]. Guangxi University for Nationalities, 2016.

[5]. Lu Yuankang, Zhou Feng, Chen Yuanfang. Local colleges and universities library discipline service a number of errors [J]. New Century Library, 2012 (4): 47-50. 